\title{
A Novel Path of Communication from Kidney to the Adrenal Gland in Bactrian Camels (Camelus bactrianus)
}

\author{
Una Nueva Vía de Comunicación del Riñón a la Glándula \\ Suprarrenal en el Camello Bactriano (Camelus bactrianus)
}

Wenling Ye*,**; Fengling Wang*; Shuangyu Lv*; Yange Wang*; Shuo Dong* \& Jianlin Wang**

YE, W.; WANG, F.; LV, S.; WANG, Y.; DONG, S. \& WANG, J. A novel path of communication from kidney to the adrenal gland in Bactrian camels (Camelus bactrianus). Int. J. Morphol., 33(4):1460-1462, 2015.

SUMMARY: The adrenal gland is an important endocrine organ in vertebrates that produces a wide variety of hormones. The anatomical results showed that the adrenal gland in Bactrian camel had a typical blood supply and innervation. Surprisingly, we found that there was a novel connection mainly consisted of fibrous tissue, blood vessels and nerve bundles between the adrenal gland and the kidney in Bactrian camel, and we named it fibrous tissue-blood vessels-nerve bundles (FBN bundle). To the best of our knowledge, this FBN bundle was the first reported in Bactrian camel, and not yet observed in other animals. While, its functions and mechanisms should be studied further. We speculated that a direct function of this novel path might be to strengthen the communication of the adrenal gland and the kidney. So this communication path might have important adaptive significance for the Bactrian camel living in arid and semi-arid ecological zones.

KEY WORDS: Anatomical; Adrenal gland; FBN bundle; Blood supply; Bactrian camels.

\section{INTRODUCTION}

The Bactrian camels (Camelus bactrianus) are special precious and valuable domestic animals that mainly live in the arid and semiarid areas of the northwest China and Mongolia. The adrenal gland is an important endocrine gland, with the hypothalamus, pituitary composed of hypothalamic pituitary - adrenal axis that has traditionally been seen as the body's "stress system", and which ultimately controls the levels of cortisol and other important stress related hormones (Hu \& Funder, 2006; Pippal \& Fuller, 2008; Marieb \& Hoehn, 2013). However, the research of the adrenal gland in Bactrian camel was seldom reported. So we investigated the adrenal gland of Bactrian camel by anatomical and histological approaches, and comparison with other artiodactyls. This study would provide credible anatomic data and information for further exploring the relationship between environment adaptation of the Bactrian camels and their special adrenal gland structure.

\section{MATERIAL AND METHOD}

Seven specimens of the adult Bactrian camels were obtained from the slaughterhouse of the Right Alasan Banner Food Company in Inner Mongolia Autonomous Region, Chi- na, and the animals were killed by exsanguination in the local slaughterhouse. Samples of kidney, adrenal glands, the near posterior vena cava, aorta and other connective tissue were separated intact and rapidly, and then fixed in $10 \%$ formaldehyde. The tissue samples were colored by injecting a solution of red oils paints in ether (1:15) into the artery one week later, and then the arteries supplying were examined by dissection. The relevant parameters were measured by vernier caliper.

The samples for light microscope were fixed in $10 \%$ formaldehyde for $72 \mathrm{~h}$, then dehydrated, cleared and embedded in paraffin. Embedded tissues were cut into 7$\mu \mathrm{m}$ thick sections and stained with hematoxylin and eosin. All the sections were photographed and analyzed by MOTIC Images Advanced 3.0 software.

\section{RESULTS}

Anatomic results. The adrenal glands of Bactrian camel located bilaterally in the retroperitoneum superior and above the kidney, were reddish or red ocher, and each adrenal gland

\footnotetext{
* School of Medicine, Henan University, Kaifeng, PR China.

** Key Lab of Arid and Grassland Agroecology, School of Life Sciences, Lanzhou University, Lanzhou, PR China.
} 
about $12(\mathrm{~g})$ in weight. The adrenal glands were fixed in the dorsal muscles by an independent fibrous capsule and fat, and movement hardly. There was a great individual difference in morphology and size of the adrenal glands. The left adrenal gland of Bactrian camel was general flat oval in shape, and about $3 \sim 5 \mathrm{~cm}$ away from the celiac artery. The right adrenal gland of Bactrian camel was generally irregular triangular in shape, only about $1 \sim 2 \mathrm{~cm}$ away from the celiac artery, and close to the posterior vena cava in its dorsal part. The anterior of the right adrenal gland was next to or partially covered with the liver and formation of liver markings (Fig. 1).

Blood supply. Each adrenal gland of Bactrian camel obtained its blood supply from three arteries: the superior, middle and inferior suprarenal arteries. They usually originated at the inferior phrenic artery, the celiac artery, and the renal artery, respectively. All these arteries had several branches forming a plexus beneath the capsule of adrenal glands. Venous drainage of the adrenal glands was achieved via the suprarenal veins: the right suprarenal vein drained into the inferior vena cava, the left suprarenal vein drained into the left renal vein flowed through the dorsal of the adrenal (Fig. 1).

Innervation. Anatomical results showed that the innervation of adrenal originates in a ganglion located in the medial of inferior phrenic artery sinus. This ganglion was cylindrical in shape, which was about $2.3 \mathrm{~cm}$ in length and $0.6 \mathrm{~cm}$ in diameter. The branches of nerve entered parenchyma of adrenal glands usually accompanying with the nearby artery, which generally was middle or inferior suprarenal artery (Fig. 1).

A novel connection between adrenal gland and kidney. We found a novel connection between the adrenal gland and the kidney that mainly consisted of fibrous tissue, blood vessels and nerve bundles in Bactrian camel, and we named it fibrous tissue-blood vessels-nerve bundles (FBN bundle). The FBN bundle passed through the adipose tissue between the adrenal gland and the kidney directly, and connected the cortex of adrenal and the renal together. In addition, The FBN bundle was free, separate with the surrounding nerves and blood vessels (Fig. 1). Regrettably, because the FBN bundle was tiny, and hidden in the fat tissue, so we could not capture the picture in the anatomic. But the histological results verified that the FBN bundle was composed of fibrous tissue, blood vessels and nerve bundles, and the blood vessels were mainly veins, the nerve bundles were always sympathetic nerves (Fig. 2a). Furthermore, we also found the sympathetic ganglia distributed in the FBN bundle located near the kidney (Fig. 2b).

\section{DISCUSSION}

Each adrenal gland of Bactrian camel obtains its blood supply, like most animals, from three arteries: the superior, middle and inferior suprarenal arteries (Marieb \& Hoehn; Harrison \& McDonald, 1966; Harrison, 1951), especially the left adrenal gland. The difference was that the three arteries supplying for the right adrenal gland all located in the inferior of the gland, here we still named the three arteries as tradition: the superior, middle and inferior suprarenal arteries. In addition, we found an artery sinus located in the bifurcation between the superior suprarenal artery and the inferior phrenic artery. We speculated that this artery sinus might play a good buffer ability of blood, and could regulate the blood flow and flow velocity. However, we couldn't observe the artery sinus located in other arteries.

Excitingly, the FBN bundle that mainly consisted of fibrous tissue, blood vessels and nerve bundles was the first reported in Bactrian camel, and not yet observed in other animals. While its functions and mechanisms will need to

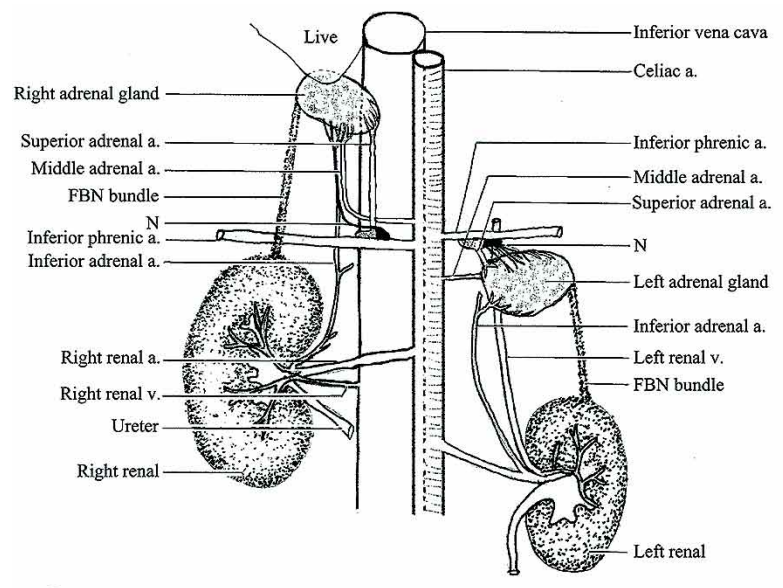

a

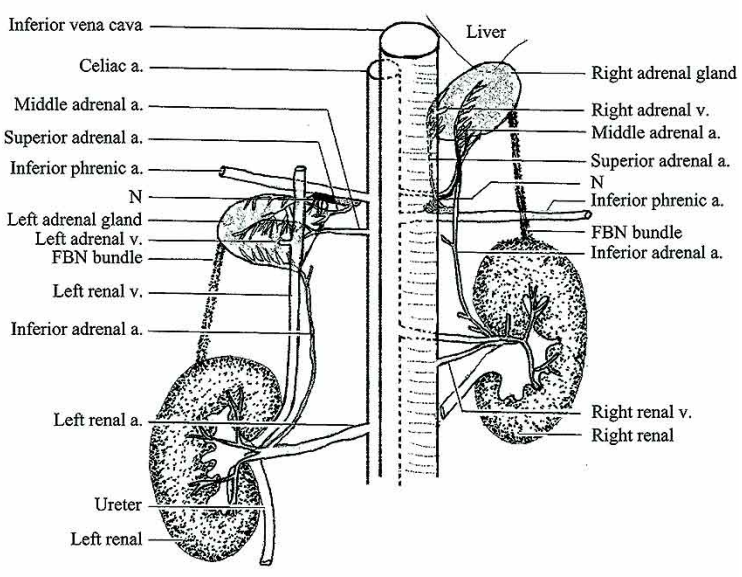

b

Dorsal view

Fig. 1. Blood supply and innervation of adrenal gland in Bactrian camel. a) Norma ventralis, b) Dorsal view. 

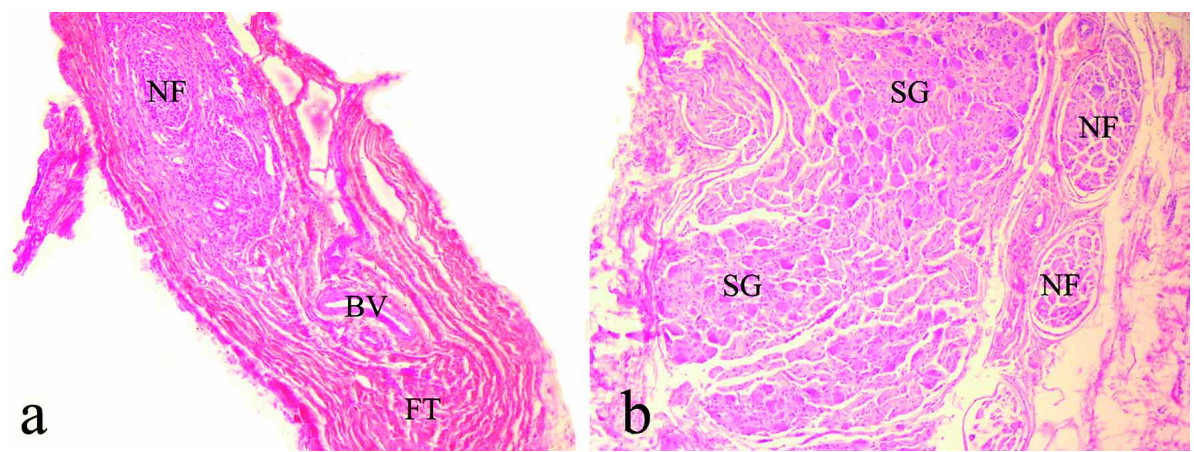

Fig. 2. The structure of the FBN bundle. a) Light micrograph of the FBN bundle in the Bactrian camel: never fiber (NF), blood vessel (BV) and fibrous tissue (FT), H\&E, x100. b) Light micrograph of the sympathetic ganglion (SG) in the FBN bundle (H\&E, x100).
RESUMEN: La glándula suprarrenal es un órgano endocrino importante en los vertebrados, que produce una amplia variedad de hormonas. Los resultados anatómicos mostraron que la glándula suprarrenal en el Camello bactriano tiene un patrón de suministro sanguíneo e inervación típico. Excepcionalmente, se encontró una conexión infrecuente que consistió principalmente en tejido fibroso, vasos sanguíneos y haces nerviosos entre la glándula suprarrenal y el riñón del Camello bactriano, denominándose haz de tejido fibroso-vasos sanguíneos-nervio (Haz FSN). Este paquete de haces de nervios es el primero reportado en el Camello bactriano, y aún no se observa en otros animales, en con-

be studied further. We speculated that the FBN bundle might help to strengthen the connection of the adrenal gland and the kidney. For example, the function of the fibrous tissue was mainly used for connection and fixation. About the veins, maybe they could transport hormones from the adrenal glands to the kidneys. The zona glomerulosa of the adrenal gland is the main site for production of aldosterone, a mineralocorticoid that is a class of characterized by their influence on salt and water balances. Aldosterone acts on the kidneys to provide active reabsorption of sodium and an associated passive reabsorption of water. This in turn results in an increase of blood pressure and blood volume (Pippal \& Fuller; Ishimoto \& Jaffe, 2011). So, we surmised that the mineral corticoid secreted by the adrenal could directly enter into the kidneys via the veins without the systemic circulation, and then regulate urinary function. Sympathetic nerves can activate the great secretion of adrenaline and to a lesser extent noradrenaline from it, and influence the formation of urine and inhibition of urination (Silverthorn, 2009; Moro et al., 2013). But the mechanism of the sympathetic nerves need to be further studied, the sympathetic ganglia that located near the kidney, would provide valuable clues. So this special FBN bundle might be related to the environmental adaptability for the Bactrian camel living in arid and semi-arid ecological zones.

ACKNOWLEDGEMENTS. This study received financial support from National Natural Science Foundation of China (39300097), and Open Foundation of Chinese Educational Department Key Laboratory of Arid and Grassland Agroecology. The authors are also grateful to Dr. Lei Zhu, Chun Yang and Zhongtian Bai for the collection of specimens.

YE, W.; WANG, F.; LV, S.; WANG, Y.; DONG, S. \& WANG, J. Una nueva vía de comunicación del riñón a la glándula suprarrenal en el camello bactriano (Camelus bactrianus). Int. J. Morphol., 33(4):1460-1462, 2015.

secuencia sus funciones y mecanismos deben ser estudiados. Creemos que podría existir una función directa de esta nueva vía para mejorar la comunicación de la glándula suprarrenal y el riñón. Así, esta vía de comunicación podría tener un importante significado adaptativo para el Camello bactriano, quien vive en zonas ecológicas áridas y semiáridas.

PALABRAS CLAVE Anatómico; Glandula suprarrenal; Haces nerviosos; Suministro sanguíneo; Camello bactriano.

\section{REFERENCES}

Harrison, F. A. \& McDonald, I. R. The arterial supply to the adrenal gland of the sheep. J. Anat., 100(Pt. 1):189-202, 1966.

Harrison, R. G. A comparative study of the vascularization of the adrenal gland in the rabbit, rat and cat. J. Anat., 85(1):12-23, 1951.

Hu, X. \& Funder, J. W. The evolution of mineralocorticoid receptors. Mol. Endocrinol., 20(7):1471-8, 2006.

Ishimoto, H. \& Jaffe, R. B. Development and function of the human fetal adrenal cortex: a key component in the feto-placental unit. Endocr. Rev., 32(3):317-55, 2011.

Marieb, E. N. \& Hoehn, K. Human Anatomy \& Physiology. 9th ed. San Francisco, Pearson, 2013.

Moro, C.; Tajouri, L. \& Chess-Williams, R. Adrenoceptor function and expression in bladder urothelium and lamina propria. Urology, 81(1):211.e1-7, 2013.

Pippal, J. B. \& Fuller, P. J. Structure-function relationships in the mineralocorticoid receptor. J. Mol. Endocrinol., 41(6):405-13, 2008.

Silverthorn, D. U. Human Physiology: An Integrated Approach. $4^{\text {th }}$ ed. San Francisco, Pearson/Benjamin Cummings, 2009.

Correspondence to:

Jianlin Wang

222 Tianshui Road

Lanzhou 730000

P. R. CHINA

Received: 02-08-2015

Accepted: 24-09-2015 